\title{
Nuclear power: the critics must be heard
}

WHEN announcing the UK government's decision to build at least one nuclear reactor per year during the decade beginning 1982 (see page 3) Mr David Howell, Energy Secretary, placed great emphasis on the need for safety.

After the accident at the Three Mile Island nuclear power plant in Pennsylvania, US last March, public fears about the safety of nuclear power are justifiably strong. And in the UK, that fear is likely to be heightened by the government's probable intention to base the new programme on the pressurised water reactor - of a similar type to that at Three Mile Island - rather than the UK developed advanced gas cooled reactor.

Mr Howell was therefore right to stress the need for safety and to reaffirm the government's intention of holding a public inquiry on the safety of the PWR before the first is built. This view is endorsed by the new House of Commons Select Committee on Energy which recently announced that the PWR is to be its first topic for study. It is to call on $\mathrm{Mr}$ Howell and representatives from the nuclear industry and the nuclear opponents as witnesses and is to pay special attention to safety.

However, what will be most important over the next two years leading up to the public inquiry and indeed, throughout the subsequent construction of any power stations, is that $\mathrm{Mr}$ Howell's promise is seen publicly to be adherred to. The need for the nuclear industry to be entirely open about its plans is greater now than it has ever been. This is not the time for it to hide behind the government's decision in the hope that it will be out of the limelight. More than ever before, public attention will be turned on it and the public will expect its opinions to be taken into account.

The major lesson which must be learned from previous nuclear debates in many countries is the need for the critics of nuclear power to have complete access to information. We endorse the government's decision to release unabridged safety reports on all nuclear power stations but would go one step further. We recommend that the Nuclear Installations Inspectorate consider the opinions of the serious nuclear critics during any future safety assessments of nuclear power stations. This means that the critics must have the same rights of access to design and safety documents and the same rights to make site inspections as do NII inspectors.

Greater openness will not be to the detriment of the nuclear industry. On the contrary, an industry which is seen publicly to be taking the right decisions about safety is one which will receive support at home and orders from abroad. Where safety is concerned, the industry should not worry about the need for commercial secrecy because the industry which is the most successful in demonstrating the safety of its reactors will be the one most successful in selling them.

Finally, the current decision should not automatically lead to the first step along the road to a major commercial fast breeder reactor programme. Rather it should be seen as a way of keeping our options open well into the 1990s. In the meantime, research and particularly the development - of alternative sources of energy and new uses for coal should be stepped up. Only after equivalent funding will it be possible to make a balanced judgement between - say - fast breeders and wave power.

\section{David Davies' editorship ends}

FOR six and a half years Nature, and much of the world's scientific community, has enjoyed Dr David Davies' work as its editor. A man of character, he has impressed his personality and leadership on the journal. A firm believer, as I am, that the specifically human characteristic of adaptability requires change to express itself, to lead to the maximum contribution and real job satisfaction, he has always lived by his precept.

Once again, he felt that the time had come to move on to a radically different activity. He has become director of the newly established northern centre for the Dartington Trust, at Barnstaple, Devon. Much as we will all miss him from his editorial desk, his new task of nurturing vitality and amenities in the rural parts of North Devon will certainly give full scope to his drive and creative thinking.

He came to Nature from work as a geophysicist in MIT's Lincoln Laboratory in the US, with particular concentration on the intricate field of the seismic discrimination and the detectability of underground nuclear explosions - efforts continually central to the much hoped for complete test ban treaty. He had come to geophysics from physics at Cambridge University.

He threw himself into his new tasks at Nature with characteristic flair and drive. His international outlook, the result of much travel and experience of work in two countries, was translated into efforts which matured into a remarkable success of making Nature a journal concerned with the progress, health, organisation and vitality of science in all countries of the world. We should perhaps be particularly grateful for the coverage of countries of the developing world, but his own intimate knowledge of the United States scene, his selection of correspondents in Canada and on the European continent, his ensuring the reporting of what goes on in the USSR and Eastern Europe, all this has lead to a global outlook of educational benefit to all Nature's readers.

Personally, I have most enjoyed his editorials, pithy, hardhitting and relevant. One may not have agreed with every one of them, but none was dull. But the journal's success is above all based on the original science it contains. It was no mean effort to have kept and increased its attraction to scientists everywhere for the rapid but responsible publication of relevant new advances. To have added to this central core of original letters a series of important and novel review-type articles in every issue has materially added to the value of the journal. The book reviews too have been a source of much enjoyment and profit to me.

His six and a half years with Nature have made an impact on all its readers. We all wish him well in his new and very different tasks.

Hermann Bondi 